\title{
Myth and Reality in Minahasan History: The Waworuntu-Gallois
} Confrontation

Mieke Schouten

Citer ce document / Cite this document :

Schouten Mieke. Myth and Reality in Minahasan History: The Waworuntu-Gallois Confrontation. In: Archipel, volume 34, 1987. pp. 119-141;

doi : 10.3406/arch.1987.2376

http://www.persee.fr/doc/arch_0044-8613_1987_num_34_1_2376

Document généré le 24/01/2017 


\section{Myth and Reality in Minahasan History : The Waworuntu-Gallois Confrontation}

I.

During the colonial period among the Dutch a definite stereotype existed of the inhabitants of Minahasa, to the extent that in the twentieth century this region was often called "Holland's twelfth province». A number of factors accounted for this label : the universal acceptance of Christianity by the population, the spread of aspects of the western way of living, a broad knowledge of the Dutch language, as well as the many Minahasans in the KNIL (Koninklijk Nederlandsch Indisch Leger, Royal Army of the Netherlands Indies).

Less known was that this people often protested against Dutch political and economic measures, which constituted a heavy burden, especially in the nineteenth century. Minahasans expressed their rejection of Dutch policy most frequently by the not very spectacular method of noncooperation (1). Armed riots were only very incidental. But from the end of the nineteenth century, Minahasans showed that they had learned to use a weapon that the Dutch themselves had delivered to them : literacy.

In this article we will concentrate on the period 1881-1892, a turbulent decade for the approximately 150,000 Minahasans of that era. The many changes then introduced by the government provoked the opposition of the population, ultimately leading to a remarkable action on the part of one of the Minahasan chiefs, A.L. Waworuntu. In 1891 this man undertook the long journey to Batavia, where he received an audience with Governor General C. Pijnacker Hordijk. On this occasion he handed him a petition in which in perfect, though somewhat bombastic Dutch, he depicted the deplorable situation in which the population of his homeland found itself. Waworuntu requested the Governor General to visit Minahasa personally, in order to 
ascertain for himself the correctness of the facts he mentioned.

Such an action by an "inlander" ("native») had never occured up to that time. It thus drew much attention in political as well as journalistic circles, even in the Netherlands. In several parts of the archipelago, Indonesian chiefs were becoming acquainted with Dutch education, western values and manners. At that time Java counted three bupati (regents) with training in the HBS (Hogere Burgerschool, secondary school). But it seemed out of the question that these would undertake such a courageous, or, if you like, impudent action as Waworuntu's. Which were, then, the causes of his action - and what was the follow-up?

In the following we will first deal to some extent with the background of Waworuntu's undertaking, and then with the survey of conditions in Minahasa which was thereupon carried out by the civil servant W.O. Gallois. We are not interested in the detailed proceedings of this survey, but mainly in the encounters between Gallois and Waworuntu, two persons with quite different backgrounds and ways of thinking. Gallois was a representative of the world of Dutch desk-bound officials who where responsible for policy. Waworuntu belonged to the first generation of Indonesian «intellectual" chiefs.

According to colonial ideology, the Dutch and the "native" world should kept strictly separate : each was a setting of its own, with its own cast, conventions, language. If contact was necessary between these two worlds, it should take place in the cultural link or schakel (2), an intermediate world which was created by the Dutch - and the Dutch determined what behaviour was appropriate there.

It was in this schakel that the confrontation between Gallois and Waworuntu took place. But, the Dutch official was to be discomfited by the degree to which the Indonesian chief wished to conform to the conventions of the schakel.

II.

In the above-mentioned petition (3) to Pijnacker Hordijk, Waworuntu first emphasized that the economic circumstances of the Minahasans were lamentable. The main difficulties were the increases in the herendiensten. (corvée labour) and taxes during the preceding few years, which in their turn indirectly caused a shortage of food.

Indeed, The Minahasan population was heavily burdened, particularly by the forced coffee cultivation. "Menado-coffee" had enjoyed an excellent reputation for a long time, and high prices were paid for it in European markets. But the Minahasans did not benefit from these.

As early as 1822 a government monopoly on coffee had been introduced, resulting in the population receiving only a low payment for their great 
efforts in cultivation. The Dutch government developped strict regulations as to how, and how much, coffee should be planted, and the persons who evaded the rules were subject to severe sanctions. In order to extend the coffee plantations, the Dutch undermined old customs, in particular those relating to land tenure and settlement pattern ${ }^{(4)}$. Much labour was required of the population. According to Edeling ${ }^{(5)}$ in the eighteenseventies a family spent an average of 120 days a year on coffee cultivation and preparation; Stakman (6) gives for the end of the eighties an average of 80 to 100 days.

Apart from coffee cultivation, the population had to work for the government in corvee labour. In the interest of the coffee transport, the government wanted a good infrastructure. But this was only completed to the cost of much effort and even many lives of workers, due to accidents, exhaustion and food shortage. Construction of roads and bridges in the highly unven ground of this region was not at all easy.

In 1852 the rice supplies which up to then had to be delivered to the government and the chiefs, were substituted by taxes, amounting $£ 6,50$ per household (later per adult male) a year. Minahasans had then, as well as later in the nineteenth century, great difficulty in acquiring this amount of money (7).

At the end of the 1870's a strong boost was given to the coffee culture : and an even stricter regulation of the corvée labour was to be introduced (8). For this purpose some Controleurs (junior Dutch civil servants) with experience in the administration in Java were stationed in Minahasa, and subsequently made themselves very unpopular there because of their harshness, producing an unprecedented social unrest. One Controleur was even killed, and several of his colleagues felt their lives threatened ${ }^{(9)}$. The new policy in regard to coffee culture had unsatisfactory results. The newly introduced "Preanger method" proved to be an outright failure, and Minahasans sabotaged the cultivation and preparation of coffee as much as they could - as they had done in preceding decades. Later in the 1880's the regulations on coffee culture were loosened. However, the emphasis on corvée labour remained.

Under M.C.E. Stackman, Resident (senior civil servant) of Manado from February 1889, the situation became more critical again. This Resident was well aware of the heaviness of the burdens for the population, especially of the coffee cultivation. Therefore, he recommended that the government gradually abolished the forced cultivation, as well as the government monopoly ${ }^{(10)}$. Other ambitious and essentially well-meant plans included an extension of the possibilities to buy off the corvée labour, and an introduction of a tax which was more proportional to income. However, the way 
in which the Resident wanted to put his ideas into effect was not a fortunate one. He increased the demand for corvée labour, giving as one motive that the people thus would feel the need to buy their way out of these obligations. Also a sharper control on the payment of tax was introduced. Bad weather conditions worsened the situation.

The problems experienced by the Minahasans in providing for their subsistence needs due to the increase in corvee labour and in taxes constituted one part of the objections of Waworuntu. He presented his objections shrewdly, always referring to the concomittant laws and regulations which he found to be trespassed by the Resident. When outlining the economic difficulties of the population, he referred to his own ambiguous position and that of the other chiefs. He argued that they felt a deep compassion for their people, but were not able to relieve their burdens. Confronted with severe sanctions, they had to obey their Dutch superiors even if they knew it was to the detriment of their people. And these in turn reproached them for this, and thus the respect and popularity which the chiefs formerly enjoyed with their people had severely diminished.

In fact, Waworuntu's most serious grievances related to the chiefs' position. They were suffering from financial problems and were treated in a humiliating way by Dutch civil servants. Their previous autonomy had been totally lost in the past years. Waworuntu mentioned several cases to support his argument in this regard. Moreover, he had some minor complaints regarding recent individual events ${ }^{(11)}$.

The chiefs to whom Waworuntu referred were the ones who stood at the head of the so-called «districts". These districts were originally the continuations of the walak, the political and social communities in which the Minahasan population was traditionally organized.

The members of the walak belonged to the same ethnic group (12) and, though dispersed in several settlements, felt a bond of common history and common customs. Through these, each walak was distinguishable from the other ones. So, in Dutch terms, the walak was the adatgemeenschap ( adat community) of Minahasans. In 1821 there were 27 districts, in a total population of about $56,000{ }^{(13)}$. In 1890 the number had - by way of government-imposed fusions - diminished to 20 , with an average of 7,000 inhabitants in each district.

In precolonial times, the direction of a walak was for an undetermined period in the hands of an elected panatu'an ("elder"), although the other walak members also had a say in decision making. It seems (14) to have been customary that a panatu'an, on account of his position, could count regularly upon some labour force, as well as upon a periodic supply of food by other walak members.

During the VOC-(Dutch East Indies Company) period, the Dutch main- 
tained contact with these walak "chiefs" as representatives of the Minahasan people. When direct rule was established in 1817, the walak were maintained as administrative units, now labelled as "districts". The position of panatu'an (now "district chief») and of his assistant kumarua (now «junior district chief"), also remained intact, as did the periodic supplies and services rendered to the chiefs by the population - though the amount was now fixed by the Dutch. So the old forms remained, while the functions of the chief underwent a great change : he was now an instrument for the Dutch exercise of power.

The government, then, derived benefit from the solid position of these chiefs. Formerly they were elected by their people, and dismissed when their legitimacy was at stake. Now, the Dutch government controlled appointment and eventual dismissal. The position remained as much as possible within one kin group, so there developed a tendency to form an administrative elite, consisting of relatives of the chiefs in the various districts. This was not just an elite in the political, but also in the economic and cultural sense. Mainly thanks to the government's support they were able to accumulate wealth (15); they received coffee commissions and a share in the taxes. And, stimulated by the Dutch, they developed a way of living that contained many western elements. They learned Malay - or even Dutch - , wore western clothes and furnished their houses in the European way. The influence of Christianity and the extensive school system, introduced in the nineteenth century, is here undefinable ${ }^{(16)}$.

The other Minahasans were also affected by these influences, but they lacked the means and opportunities to obtain the same education or attain the living standard as the notables.

According to Dutch colonial policy, Minahasan chiefs, though volkshoofden (17) and deriving their functions from the old institutions, had to stand above their people in a more salient way, and thus exercise a special authority. Then they would be in a better position to help the Dutch to execute the planned measures. Their outward status was augmented by the procurement of special marks of power (e.g. staff and parasol, in fact attributes of Javanese princes $\left.{ }^{(18)}\right)$, titles and privileges.

So there emerged a clear distinction between the chiefs and the rest of the population, in the political, economic, and cultural spheres. But certain traditional institutions remained in force : chiefs were appointed only in districts from which they originated, and the population at times had to perform work for them. With the small size of the districts, it was thus possible (notwithstanding the gap mentioned above) that a personal bond remained between chiefs and their subject populations. They derived their authority over the people partly from the character of this bond, but also partly from the Dutch, who protected them and had granted a special sort of status. 
A threat to this status, however, came precisely from the Dutch. In 1881 new regulations concerning the position of the chiefs were promulgated (19). According to these, the economic basis of the chiefs, which initially lay with their population, was transferred to the government. The providing of services and supplies by the population was abolished (20), and the chiefs received a fixed salary. Anyone, even those not belonging to the chiefly families or even to the district in question, was to be considered for the post of district chief, if he met certain requirements. In addition, chiefs could be transferred frequently. So, now the position of the chief was becoming more or less identical to that of a civil servant.

The chiefs felt humiliated by these new regulations : their relative autonomy had come to an end, and their standing had declined in regard to their own people as well as in regard to the Dutch. They were now completely absorbed in the administrative hierarchy, on the lowest level. They had to pay obedience to the Controleurs, who were often a generation younger than the chiefs. The self-respect of the latter was further impaired by Resident Stakman, who in 1891 abolished the staff and parasol, which as marks of honour were of great symbolic value for the chiefs (21).

All the chiefs found it hard to become accustomed to the new status; it demanded the greatest effort, of course, from those who had already had a long career in the administration of their district (22). Of these, a remarkably high number resigned in the beginning of the eighties, and were replaced by young chiefs. One of these younger ones was A.L. Waworuntu, who in 1891 acted as the foremost advocate of more autonomy for the district chiefs. As he had known the pre-1881-era only as a child and a teenager, it cannot be assumed that his action was inspired by nostalgia. A glance at his antecedents is worthwhile.

III.

The chiefs of the district of Sonder during the nineteenth century were remarkable personalities.

In 1829 , when the Minahasans provided the Dutch with a contingent of 1,400 men as an auxiliary force in the Java War, these troops were led by H.W. Dotulong, then chief of Sonder. Thanks to this contribution, he and the following chiefs of Sonder were allowed to bear the title of majoor (23).Some other district chiefs also obtained this title, but the Dotulong was the "senior" majoor and bore his title in an impressive way. In the entire Minahasa region and also among the Dutch, he enjoyed great authority due to his outstanding personality (24).

In 1861 Dotulong was succeeded by his eldest grandson (the son of his daughter and the chief of the district of Sarongsong), Albertus Bernardus 
Waworuntu. In 1845 this man had been chosen by the Governor of Amboina as "one of the most able well-born young men" to study the wet rice cultivation in Java ${ }^{(25)}$. After his return in his homeland he occupied various posts in the administrative corps, including that of chief jaksa (judicial officer). From this position he moved to that of majoor of Sonder. His execution of his administrative duties so impressed the Dutch that in 1876 they awarded him the gold medal of civil merits, an honour which before that year had never been earned by a Minahasan (26).

A.B. Waworuntu had married the daughter of the chief of the district of Manado, and to them four children had been born. Albert Lasut, the eldest, was born in 1862, when his father had just succeeded his greatgrandfather as the chief of the district of Sonder. His education was typical for that of a son of a Minahasan district chief at that time : he attended the Europeesche Lagere School (European Elementary School) in Manado, and then the School for Sons of Chiefs at Tondano. Already in 1880, at the age of eighteen, he was assigned to assist his father as hukum kedua (junior district chief) of Sonder; he performed in this position to the full satisfaction of his European superiors, who valued not just his administrative, but also his intellectual capacities. He assisted then the Controleur of Amurang, E.J. Jellesma, in his study of Tontemboan, the Minahasan language spoken in the district of Sonder and some others. Waworuntu himself also published in the Verhandelingen van het Bataviaasch Genootschap (27). He knew most of the Minahasan languages perfectly and for this reason he was summoned to Makassar in 1886 to function as an interpreter at the Council of Justice during fourteen sessions (28).

Waworuntu was in an even better position to show his qualities in the field of administration when he had succeeded his father as majoor of Sonder, in 1887. Soon he received the silver medal of civil merits. Amongst other things, he designed and had exccuted important irrigation works for the laying out of sawahs, and drafted a juster regulation for taxes and corvee labour in his districts. His rule was evaluated favourably by the about 10,000 inhabitants of Sonder. He seems to have been a charismatic personality of great sociability. The fact that he originated from one of the most prominent Minahasan kin groups, and that he was affiliated with some other notable families, must also have had a favourable effect.

With this background Waworuntu seemed to have a guaranted future before him, in which he could bask in the affection of the Dutch as well as in that of his own people.

And this all he was to put at stake, after the coming into service of Resident Stakman. Some of the older chiefs, to whom Waworuntu was related, had from the outset a bad relationship with this Resident. Waworuntu him- 
self, too, got soon into troubles, though there was no open conflict. In the negative opinion on conditions in Minahasa, he knew he had the support of some former Dutch civil servants and other Dutchmen with whom he had developed a friendly bond during his administrative career (29).

When in 1891 he was granted sick-leave because of a chronical inflammation of the larynx, he used this opportunity to draw in a unique way attention to the fate of Minahasan chiefs and people. He travelled to Java, to consult the specialist on throat diseases, C. Winckler. Besides, he tried to obtain a special audience at the Governor General's, which was permitted him in December. On that occasion he handed him the above-mentioned petition.

\section{IV.}

It was not completely unknown in Buitenzorg, that the situation in Minahasa was alarming. The Commission for Reconsideration of the Government's Coffee Cultivation, which was operating at the time, had already paid circumstantial attention to Minahasa, and there was a general opinion that the government's coffee monopoly and forced cultivation were very oppressive to the Minahasans, certainly in combination with the other duties to which they were subjected (30). Indeed, in 1891 Resident Stakman wrote a memorandum to the Commission with several recommendations, in which he showed insight into the heaviness of the burdens, and his intentions to relieve these $(31)$.

Soon it became clear that the measures he had already begun to take in order to bring about this relief had instead the opposite effect. In the press of 1891, there had already appeared some criticism of Stakman's policy, varying from protest about injustices to which a single Minahasan chief, or the chiefs as a group, had been subjected to outright expressions of distress concerning the economic situation in which the population had found itself for some years ${ }^{(32)}$. There were rumours, that the Governor General had plans to come to Minahasa in person, and Waworuntu alluded to these in the concluding passage of his memorial.

The fact that an Indonesian had submitted a petition with such a critical content to the Governor General immediately provoked considerable commotion in leading government circles. The press made it public, and saw in it sufficient reason to dwell still more extensively on the conditions in Minahasa. There was a little else the Governor General could do than to arrange an investigation into the backgrounds of the complaints and into the general situation in Minahasa. He charged with this mission a member of the Raad van Indië (Council of the Indies, the highest advisory organ to the Governor General), W.O. Gallois. 
Gallois had spent his life since the late sixties in the official atmosphere of Batavia and Buitenzorg. He had started his career as a clerk at the General Secretariat, later attained higher positions, and, in 1887, became general secretary of the government. In 1889 he became a Ridder in de Orde van de Nederlandsche Leeuw (Knight in the Order of the Dutch Lion). He commenced his membership in the Council of the Indies in April 1891 (33).

The choice of Gallois was generally criticized. His general education and his probity as a desk-official were not doubted. But the critics pointed to the fact that he had never worked outside the central bureaucracy and had no clear idea of the actual functioning of the territorial Binnenlands Bestuur, which was responsible for the implentation of government policy in the various regions of the archipelago. The Indische Gids noted that Gallois had made his career at the General Secretariat, which, by taking no account of history and customs of specific ethnic groups, was in large measure to blame for such injustices as those perpetuated on the Minahasans (34). A major point of all the criticism was that Gallois had hardly ever communicated with Indonesians, except casually in Batavia and Buitenzorg. And this lack of experience was expected to be very disavantageous for his present mission, in which he was supposed to listen carefully to the complaints uttered by the Minahasans themselves. Therefore, before his mission had even begun, doubts had been cast on the neutrality of the investigator.

V.

Saturday afternoon, the 19th of March 1892, Gallois's boat arrived in the port of Manado. The government's delegate was welcomed by Resident Stakman, who no doubt felt ill at ease with the mission of this high guest who came to investigate the validity of complaints raised against his policy. Shortly before, he had taken some measures that might help to favour the outcome of the survey, e.g. the decoration of four district chiefs. And in the following weeks, he would do anything to make the delegate's stay as pleasant as possible, as well as to avoid the impression of influencing Gallois' survey.

That weekend Waworuntu was also in Manado; he had returned to Sonder from his Java-journey on the 2nd of March. On the 20th of March he asked - in a letter written in Dutch - for an audience with Gallois. He obtained this on the morning of March the 21st.

The daily Bataviaasch Handelsblad later issued an extensive report, dated 25th of March, of the conversation between Waworuntu and Gallois, which can hardly have been written by anyone else than Waworuntu himself. According to this account (35): 
"When he was admitted to His Honour's presence and had made his bow, the Government's Commissary assigned him a chair, and when he sat down, His Honour addressed him in Malay, and the district chief regretted this because he knew that a conversation in Dutch would have been much plainer to Mr. Gallois. Mr. Gallois treated everyone very haughtily and I am sure that if His Honour acts in the same way to others, whether common people or chiefs, as towards the said district chief, the people who come to him will be easily intimidated and will have difficulty in keeping cool. Mr. Gallois first asked the Majoor Sonder if he had come to Manado with the permission of the Resident. The districtchief answered that it was customary in the Minahasa that the Majoors or Hukums Besar, when they leave their districts for some days, make this known in a letter to the Controleur of the Afdeeling (Division). Permission is needed only if they expect to stay outside their districts for weeks or months. After that he said that, now that he was in Manado and knew that His Honour had come to Manado to investigate the affairs he brought forward to His Excellency the Governor General, he also considered it his duty to introduce himself to His Honour.

Thereupon Mr. Gallois said that His Honour had learned from the Resident and also from the Controleur that he was a good native chief, and that therefore he was most surprised that he had lodged a complaint with His Excellency the Governor General against the Resident. Waworuntu answered that he had not gone to His Excellency for personal reasons and that he first had given serious consideration to all he had done, but that he had regarded it as his duty to take this step, to bring about an improvement in his native land.

He said : "I have a wife and four children, father, mother and relatives, and I knew already beforehand that, by revealing my objections to His Excellency the Governor General, I would risk my office, my future and my peace." And he continued : "If Your Honour wants to know the truth and the full truth, then an accurate investigation will reveal that everything I have said to His Excellency the Governor General is true, and that even much more has occured in Minahasa than I have already brought to the high attention of His Excellency". Thereupon the Government's Commissioner took the memorandum which the district chief had offered to the Governor General, and began to deal with the subjects one by one. I hope that I misunderstood, but from the way Mr. Gallois and the Controleur First Class for the Outer Possessions, Mr. Kerkhoff (36), who was assigned to him, dealt with the affair, I am inclined to conclude that they wanted to defend everything which has been done by the Resident, $\mathrm{Mr}$. Stakman, and where the facts were too clear, they just wanted to put the blame on the indigenous chiefs."

From this quotation some points of tension between the chief and government's delegate immediately become clear. Gallois only wanted to speak in Malay, although he knew that Waworuntu had a thorough command of Dutch. But this was hard for a Dutch civil servant to accept. A conversation in Dutch, in his opinion, would have signified an admission of Wawo- 
runtu's status as equal to that of Dutch civil servants. Gallois believed that Waworuntu must be strongly reminded of his place as defined by the colonial government. And persistence in speaking Malay was one of the tactics used towards educated Indonesians during the entire colonial era, to make them conscious of Dutch mastery.

Besides his use of Malay, which already could be conceived of as an "insult», there was also Gallois's insistent and reiterated questioning regarding permission for the chief to leave his district. Finally, Waworuntu explained that he had come to Manado in the first place to consult the physician, Dr. Bijker. But, Gallois did not accept this coincidence; indeed, he later learned that the Majoor had not been received by the physician recently.

Resident Stakman also called Waworuntu to account regarding the assumed lack of justification for his sudden leave from Sonder. But the latter argued that he had a valid reason for his journey to Manado : he had indeed come to see the physician. With the very same ship that brought Gallois, Waworuntu expected an important letter from Dr. Winckler - the specialist in Java - to Dr. Bijker, concerning the treatment of Waworuntu's disease. However, before he went to the physician's house, he had learned that the letter had not arrived (37).

From this incident, the extensive control to which the chiefs were subjected becomes obvious. Individual initiative was certainly not appreciated. They had to obey to the rules, quite literally.

And now the Dutch civil servants in Minahasa were keeping a special watch on Waworuntu. The Resident deliberated with the government's deputy how he should behave towards the man who of late had been acting so independently. Stakman wanted to maintain the authority of the government over him and the rest of the population without obstructing the investigation, which was so obviously related to Waworuntu's actions. Gallois answered that the Resident could take the measures he thought fit to bridle the Majoor. He advised him to call him to account and let the further way of acting depend on the way in which Waworuntu defended himself (38). Thereupon, Stakman immediately wrote a letter to the Majoor of Sonder, pointing out various cases of apparent neglect of duty since his return to Minahasa (39). Waworuntu's extensive response ${ }^{(40)}$ was apparently sufficient, for the time being, as the Resident did not take any steps.

Let us return to the quoted report in the Bataviaasch Handelsblad. In the final part the writer assumed that Waworuntu's objections would not be taken seriously, and that failures would always be attributed to the chiefs, rather than to the European administration. The attitude of Gallois towards Waworuntu and the other chiefs he met during his first days in Manado apparently gave rise to this assessment. Indeed, during his survey Gallois 
was to make it clear that he did not consider the district chiefs as victims, but rather as co-authors of the unsatisfactory elements in the situation.

After a stay of about two weeks in Manado, Gallois left for a tour through Minahasa. His purpose was to inquire into the economic situation in each district. However, the more thorough investigation he left to his secretary, the Controleur C.E.P. van Kerkhoff.

During this tour, many people made their objections known, frequently in a written petition. These finally numbered 784 in total. Minahasans, commoners and leaders, now saw the advantage of their mastery of the art of writing (41). The contents of these petitions were heterogeneous : common villagers usually complained about the pressure of corvée labour and coffee cultivation, and calculated that they were left with a few days in the year to provide for their own subsistence. Others, especially those who maintained a job in the church or the school or who had ever held a position to the local administration, requested an exemption from taxes and/or services. Many chiefs or villages and especially of districts argued they were not treated properly, or wanted an improvement in their material benefits, or a return of privileges shortly before taken away from them. Many of them also complained about the general circumstances or their area of jurisdiction.

In each district capital Gallois called for a survey of corvée labour. Besides the Controleur, the chief of the district in question was usually present, as well as village-heads or some other indigenous functionaries. When Gallois and his entourage came to Sonder for the survey, A.L. Waworuntu was prevented from rendering assistance because illness. He was replaced by the junior district chief, his younger brother E.W.J. Waworuntu. The zeal with which this man took notes during the survey aroused Gallois's suspicion, and he was convinced that these notes were later handed to his brother (42). As a proof, he pointed to several critical articles in Dutch East Indian dailies, that included reports on the survey (43).

VI.

Gallois certainly had never before experienced, and would not have expected attitudes and behaviour such as those of Waworuntu from any Indonesian, and he must have felt uneasy. But, being a high-ranking Dutch civil servant, he had many possibilities for neutralizing this opponent. In his reports, he gave cutting indictments of him. He argued that before his journey to Java Waworuntu was considered one of the best educated chiefs, and fulfilled his duties very well as an administrator. But «the behaviour of the chief of Sonder, after his return from Java leaves so much to be desired, that his ability to function is endangered" (44). He thus alluded to a possible dismissal of Waworuntu, primarily on the grounds of his «imperti- 
nence». Gallois had experienced this on several occasions and seems to have been shocked. For example, Waworuntu, before the start of the inspection tour had offered himself to act as an interpreter for the various Minahasan languages. It goes without saying that Gallois was not anxious to make use of Waworuntu's services (45). And then, was it decent for a district chief to lodge complaints against a Resident?

Those complaints had served as the basis for Gallois's mission to Minahasa. Although he did not mention explicitly Waworuntu's petition in his official report, he paid detailed attention to its contents in his rough notes and secret correspondence (46). He did not carry out a thorough investigation into the minor complaints; conversations with the Resident and Controleurs usually seemed sufficient for him to invalidate them. He also explicitly recorded admissions by the Majoor of Sonder that some of the regulations which he had assaulted had no longer been in force for some months (!).

But Waworuntu's main points of protest remained. Gallois had to admit that "the material conditions of the population leave much to be desired" and that indeed in some places famine prevailed. The recent policy was partly to blame. In his official report $(47)$ he concluded that the heaviest burden was the forced coffee cultivation, but that the frequent exceeding of the legally maximum number of days in corvée labour also had a highly unfavourable effect. On the average, the Minahasan men were left with only 90 days a year to provide for their subsistence. Soon after Gallois's mission the government monopoly on coffee was to be abolished. This was not unexpected, given the recommendations of the Commission for Reconsideration of the Government's Coffee Cultivation (see above), but now the procedure seemed to be accelerated. Gallois's survey had drawn the attention of Dutch Members of Parliament especially to Minahasa. The report gave rise to many questions and much consideration during the debates on the budget of the Indies for 1893 (November 1892) (48).

For the other main element of Waworuntu's address, viz. the damaged position of the chiefs, Gallois had no sympathy at all. On the contrary, he thought the chiefs still had much too comfortable a life. Some of the abuses that he noted he saw as a result of the failure of the chiefs. They had problems in adjusting to their new economic position as civil servants, and they still made use of labour provided by the population. In his report Gallois emphasized the impertinence of the chiefs towards him and their Dutch superiors : "Many chiefs are apparently not yet sufficiently impressed by it ( = their subordinate positions), and anyway, the tone and attitude some have dared to adopt recently are not in accordance with their real position.» (49). He suggested that from then on chiefs should without exception be appointed in districts from which they did not originate. Thus, the personal character of the relationship between chief and district inhabitant 
would be further reduced, and the chiefs, while exercising their office, would not be able to exploit their land, and thus not be able to obtain «illicit» income.

But the Governor General, as well as most members of the Council of the Indies, were of the opinion that Gallois's recommendations in this regard were too far-reaching. They argued that by conserving some of the «traditional" aspects of political leadership the chiefs were in better position to obtain the respect and the trust of the population, and could thus better act as an intermediary between the Indonesian population and the European civil servants ${ }^{(50)}$. So, notwithstanding the progressing bureaucratization in Minahasa, the ideal of the volkshoofd was still very much alive in government's circles, one of the characteristics paradoxes in colonial ideology.

Gallois could not absolve the Dutch civil servants from blame. He concluded that Resident Stakman had some good intentions, but had been too rash. In his relationship with the chiefs, he had acted undiplomatically. Gallois advised the Governor General to appoint Stakman in another Residency. He should not be pensioned off, because then uthe chiefs would become even more arrogant and self-conceited by that success, and would try to lay down the law for the successor» ${ }^{(51)}$.

The Governor General did not follow the last part of Gallois's advice integrally. Stakman was given a hint to apply for an honorary dismissal; he did so in an embittered letter ${ }^{(52)}$. At his official dismissal, he published a counter-plea (53), addressed to the Parliament, to defend his policy. $\mathrm{He}$ blamed Gallois because of his fast and superficial investigation. As a result, several findings and conclusions were not in accordance with reality. There were also many discrepancies between the conclusions Gallois had drawn during the investigation and those which he published. Stakman imputed this to the influence the criticism in the press had on Gallois. The proposals for reform at the end of the report were in large part identical with those Stakman had already made before, in particular in his Advice for the Coffee Commission. And the retired Resident regretted that Gallois had failed to publish an outright invalidation of Waworuntu's complaints. This task Stakman now posed for himself, and used several dozen pages to accomplish it. He did not hesitate to attack the Majoor of Sonder personally (54). However, he was of the opinion that the role of Waworuntu was unimportant in the commotion, and that the latter had simply been used as a tool of some older malcontent chiefs, to whom he was related as a kinsman. The Gallois-investigation was said to be provoked by these chiefs because they could not accept the decline on their status and wealth, and because the Resident had tried to counter their "illicit» practices. 
Altogether, Waworuntu's action brought about - directly or indirectlymany changes in the short term that were positive for Minahasa : the broader attention for the region; the replacement of Stakman by E.J. Jellesma, who in the early 1880's was popular among Minahasa as a Controleur; and the increase of the selling price of coffee, later followed by an abolition of the government monopoly and forced cultivation.

\section{VII.}

The complaints about the poverty in Minahasa were generally correct. The way in which the complaints were lodged, however, caused uneasiness among the Dutch.

To the outer world, Waworuntu acted for himself and thus attracted all the attention to his person; in fact, his action was supported by others chiefs, or anyway met with a wide response among them.

The protest movement and the commotion it engendered would not have taken place in this way, had not the Dutch provided education to the Minahasans. The colonial regime had paid special attention to the training or future chiefs since the first half of the nineteenth century, precisely because it wanted to improve the skills which it deemed necessary for chiefs. They would become better members of the administrative corps, thus facilitating control over them. The chiefs had to join in the schakelsociety. They were stimulated to adopt some western habits in order to facilitate contacts with their superiors. But their bonds with their own people had to be partially maintained. In this way, the chiefs really could act as a link, as cultural brokers, between the mass of the population and the Europeans, exactly as the latter wanted it.

The Dutch had not foreseen, however, the chain reaction which was to be caused by their, as they thought, carefully dosed provision with western knowledge and skills. Minahasan chiefs, but also other members of the population, wanted more and more of it. This applied in particular to knowledge of the Dutch language. Its progressive spread aroused much criticism amongst civil servants. It was argued that a Minahasan would then become alienated from his own culture. But the real fear was that Indonesians would get access to domains which as a matter of fact were reserved for the Dutch. Dutch administrators reasoned that publications critical of the government could then be read by Minahasans, a fear which had existed since the 1870's (55).

Mastery of the language also enabled Minahasans to reach the Dutch public and in particular the policy-makers with their points of criticism. This had become very clear in the period of the Gallois-survey, though that was not the first time. In 1877 en 1878 the Minahasan chiefs, supported by some 
Dutch, had already addressed themselves by way of a neatly worded and argued petition to the Governor General and then, this having had no results, to the Dutch Parliament (56). Their aim was a revocation of the socalled Domeinverklaring, the law that declared all uncultivated land in Minahasa state property. The action, which remained unsuccessful, aroused the anxiety of some civil servants, who saw in it a proof of «premature emancipation" (57), the negative outcome that education in Dutch could have (58).

This earlier action had apparently only been inspired by the self-interest of the chiefs, but this was not the case with Waworuntu's action. His complaints concerned the chief's position, but also the condition of the entire population. However, many Dutch considered also here self-interest as the determinant. They pointed to periods in the nineteenth century in which the economic situation was worse, and the regime more severe than in the early 1890's. For instance, where was the protest of the chiefs in the 1850's, a far harder period ? (59)

During the entire nineteenth century there had indeed been reason for the chiefs to protest on behalf of their people. But it took some time before Minahasans really had the skills, as well as the opportunity, to protest in the way they considered most suitable and effective. That time arrived around 1890 . The decline of the chiefs' status presumably constituted the real inducement for the protest then, but it should also be granted, that the chiefs were really concerned about the impoverishment of their people.

The chiefs who wanted to protest were fortunate to have among them someone who was completely familiar with Dutch conventions and language and moreover had the necessary courage. Importantly, his conduct till then had been irreprochable, and he was a favourite of the Dutch.

However, Waworuntu ought not to be regarded as a plaything of other chiefs. He almost certainly carried out his action for the greater part on his own initiative, for he had a great interest in it. Several chiefs desired a return to the old situation in which they could operate more independently. Waworuntu, too, wanted more autonomy, but he directed his gaze not at the past but at the future.

Look at his personality. His education had been the best available. $\mathrm{He}$ was, moreover, an independent thinker, endowed with extraordinary intellectual capacities. Besides, he was favoured by his descent, as a scion of one of the most notable Minahasan families. But, at the age of 26, he had already achieved the highest position which was then obtainable for a Minahasan : the post of Majoor (60). And still he was subordinate to the Controleur, and his actions were strictly checked, a situation which he must have found humiliating.

Moreover he felt blocked in his aspirations : he thought he had greater capacities than those of a mere low-ranking civil servant. 
In presenting his petition he already revealed some of his abilities and ambitions to the outer world; perhaps therefore too he expected, as instigator of the investigation, special treatment from Gallois. However, the way the latter actually acted towards him, must have enhanced Waworuntu's feelings of bitterness and powerlessness : as before, he was treated as a subordinate, or even worse, as a fraud.

In the schakelsociety, in which Gallois and Waworuntu met each other, Gallois played the part the Dutch considered appropriate when mixing with Indonesians. But Waworuntu refused to obey its conventions, which he considered unjust. This cause serious tension between our two principal characters.

Doubtlessly, Waworuntu was aware of the Dutch ideas about «inlanders", which were ideological justifications for their domination : "natives" had no great aptitude for western education, could not act independently, and their princes and chiefs were by definition exploitative. One of the aims of Waworuntu's action must have been to break through this myth, and to prove convincingly that reality was different. But, as was obvious, Gallois, as well as Stakman and the other Dutch civil servants were not to be reached by this intention. They wanted to preserve the myth of the dependent Indonesian, a myth they had created and in which they were trapped themselves. The existence of someone who evidently did not fit this long established image did not necessarily disqualify these ideas. No, it meant that there was something wrong with the Indonesian in question, and therefore he should disappear from the stage.

Waworuntu experienced this himself : after his audience at the Governor General's his main adversaries frequently alluded to his possible sacking, and indeed within a few years he was dismissed, albeit honourably because of illness. He remained active in politics, but behind the scenes, where he knew he could attain more ${ }^{(61)}$. He finished his active life with a membership in the Volksraad ("People's Council», representative body of the Dutch East Indies population with only advisory power) from 1918 to 1924 . And Gallois, without problems, went on his successful career to become Vice-President of the Council of the Indies in 1895.

\section{NOTES}

A preliminary draft of this article was presented at the second Indonesian-Dutch historical conference at Ujung Pandang, June 1978. This has now been fully revised. In the present 
version new data have been worked up which were collected when I executed research on Minahasan social history from 1981 till 1984. This research was supported by the Indonesian Studies Program in Leiden, the Netherlands. I express my thanks to Heather Sutherland, Henk Schulte Nordholt and Greg Acciaioli who commented upon an earlier draft of this article.

1. The usual method of non-cooperation was sabotage directed at coffee cultivation : the ripe coffee-beans were destroyed, thrown away or buried (see Jansen 1861, p. 225, and the Cultuurverslag of Menado, 1853, Arsip Nasional). Also people often took to flight, in order to avoid forced cultivation or corvee labour.

2. For a discussion of this concept see Taufik Abdullah, in particular pp. 148-151. He argues inter alia that the schakel "could serve as a channel through which the two strange worlds shared something without endangering their respectve basic cultural assumptions".

3. Included in exhibitum 12-3-92/51 (ARA); also in Stakman 1893, 97-114.

4. A good survey of the history of Dutch policy regarding coffee cultivation in Minahasa during the nineteenth century is by Wessels, 1891.

5. Edeling, Verbaal 17-4-77/20 (ARA), p. 862-863.

6. Stakman, 1892, p. 728.

7. A monetary economy was introduced to Minahasans when the Dutch began to compensate the coffee deliveries in money, instead of linen, in 1825 . The selling price of coffee was very low during all of the nineteenth century, certainly when compared with the actual market price.

8. These reforms had been advised by D. Ples, who made a survey of coffee cultivation in Minahasa in 1877/1878. His general report, dated August 20, 1878, is included in mailreport 192/1881, ARA.

9. The Controleur of Kema, H. Haga, died in September 1879 as a result of an attack on him by some burgers (originally allochtonous residents under Dutch jurisdiction) who were forced to perform corvee labour, an obligation from which they had been free up to then. The following month there were three attacks on the Controleur of Tondano, and some Dutch civil servants surmised from utterances made during a bellicose traditional meeting in South Minahasa that there was a conspiracy to kill the Controleur of Belang. The setting on fire of the school annex church in Tondano was considered another sympton of unrest (mailreports 641 and 893 of $1879:$ pp. 122, 170, 772, 832, of 1880 (ARA); and Kolonial Verslag on 1879, p. 17-18).

10. See Stakman, 1892.

11. These minor complaints included:

- the instruction for Minahasan civil servants (chiefs, teachers) to receive personally their salary at the Controleur's offices, which caused loss of time.

- the high costs attached to the procuring of an uniform, obligatory for the district chiefs.

- the giving of priority to an Indo-European above Minahasans in an administrative function.

- the exclusion of district chiefs from assisting at judicial sessions.

- the discharge of a village-head because of his refusal to offer his daughter as a concubine to a Controleur.

- the domeinverklaring (agrarian legislation of 1877, according to which all uncultivated land was declared state property) was also applied to land in hereditary property. An uncle of Waworuntu's, junior district chief of Manado, who protested against the levying of distress on his grounds, was therefore punished with a two weeks arrest.

- the Bantik, a small tribe in Minahasa, were impeded in the practice of their ethnic religion.

12. The Minahasan population consists of eight ethnic groups : Tonsea, Tontemboan, Tom- 
bulu, Tondano, Tonsawang, Bentenan, Ponosakan, Bantik. Most of these ethnic groups were divided in a number of walak.

13. Source : Reinwardt, p. 583. The basis and reliability of this figure is uncertain.

14. Reconstructing the political situation of precolonial Minahasa remains a precarious undertaking. This sphere was the one the first affected by the influence of the Europeans since the sixteenth century.

15. Because they now remained in office for a long time, they could develop a long-standing relationship of patronage with their people. They could oblige them, and by way of the institution of services obtain more land. The Dutch considered this as a proof of their exploitativeness. But the chiefs were expected to share their wealth with their subjects on certain occasions. (A more extensive discussion of the economic differentiation in the nineteenth century is to be found in my forthcoming doctoral dissertation.)

16. In the nineteenth century, Protestant missionaries converted almost the total population and established more than 100 elementary schools, and some schools for further education. The network of government's elementary schools was extended after 1871. By 1865 there was a School for Sons of Chiefs in the town of Tondano; a school for daughters of notables was founded in 1881, supported by the mission.

17. Volkshoofd was the usual name used by the Dutch for the Indonesian chiefs, who were considered as an embodiment of the old customs and institutions. In this way, the Dutch thought, the relationship with the past, the "tradition", was maintained. But, on the other side, these chiefs were expected to participate in the Dutch-created administration. See on this contradiction Sutherland, 1975 (in particular p. 75) and 1979 (in particular, p. 31-44).

18. These were granted in 1859 by the then Resident Jansen. See for his considerations the memorandum composed in 1856, included in Verbaal 10-3-1892/38 (ARA).

19. By Staatsblad 18, 19 and 47 of 1881.

20. In 1882 in Java a similar measure was taken, namely the abolition of pantjensdiensten.

21. Instead, a uniform was introduced. See for the considerations in this question, Verbaal $11-8-1891 / 26 ; 10-3-1892 / 38 ; 10-11-1892 / 71$ (ARA).

22. These chiefs registered all kinds of complaints, some of which at first sight may seem trivial. Some chiefs disapproved of the duty to keep a "correspondence-book" (an exercisebook in which all official business had to be written, and which had to be delivered to the Controleur). According to one chief, this exercise-book made him a schoolboy. Another chief, who untill 1881 had fulfilled his functions in a way the Dutch highly appreciated, after that year had trouble in working with almost all the succeeding Controleurs. His complaints were various, but always contained the same core : the Controleurs behaved like adolescents; they demanded too much labour from the people; and, above all, they did not approach the chiefs with the proper respect. The district chiefs in question even felt treated "as a coolie and that in the presence of others, thus taking away all their respect for the chiefs" (quoted in Bataviaasch Handelsblad of 2-7-1892, also in mailreport 643/1892). The district chief in question was the one of Pasan-Ratahan-Ponosakan. The long list of his frictions with Controleurs, extending throughout a protracted period, is included in the Nieuwe Rotterdamsche Courant, of 11-1-1893, also in Verbaal 18-2-1893/60. See also exhibitum 18-3-1893/92, and Verbaal 1-3-1893/18 (ARA).

23. The title of majoor in fact originated from the time of the Spanish influence in Minahasa ( \pm 1560-1650). The title of the other district chiefs was hukum besar.

24. See for descriptions of Dotulong: Korte aanteekeningen betrekkelijk de Minahassa, no. 165 of Residentie Archief, Manado, Arnas, p. 5-6; Quarles van Ufford, p. 40; Van der Crab, p. 349-350; Graafland, p. 205-209.

25. Originally the Minahasans knew only dry rice-fields. The Dutch made many attempts to introduce sawah-cultivation.

26. In 1876 the chief-jaksa A.B. Kalenkongan also obtained this decoration. See for a brief 
biography of A.B. Waworuntu : Van Gent, pp. 84-85.

27. Jellesma's and Waworuntu's studies have been published in Vol. 47, part 1, of the Verhandelingen van het Bataviaasch Gerootschap.

28. See the letter by Waworuntu, d.d. 21-3-1892, in Collectie Gallois, inv. no. 1, lit. L. (ARA).

29. One of these was the retired Resident of Manado, J.C.W.D.A. van der Wijk (1885-1889), who lived at the time in Sukabumi, Java. In the Netherlands the former civil servant F.S.A. de Clercq advocated Minahasa's (Waworuntu's) case. What exactly was the role of these persons, and of other Dutchmen who stood at Waworuntu's side, remains as yet unclear.

30. See various articles later published in Tijdschrift voor Nederlands-Indië, 1894.

31. Stakman, 1892. The Resident was of the opinion that the "Minahasa-population was treated more cruelly and more barbarously than the negro slave" (p. 724). It is remarkable that he heeded the distress of the population, which he regarded as the most heavily burdened of Indonesia (p. 729), as well as the vulnerability of the position of the chiefs in their relations with the government (p. 725-726). He offered many proposals to relieve the situation, including a salary for village-heads and the release of coffee cultivation, as well as of the government monopoly. This all would then be compensated by an increase in the taxes to $£ 18$.

32. In the Indische Gids of 1890 (p. 504-505) and 1892 (p. 130) there were publications, based on articles in Het Vaderland, critical of the dismissal of the chief-jaksa A.B. Kalenkongan. In the article "Grieven uit de Minahassa", Algemeen Handelsblad of August 9, 1891, criticism was expressed on the new regulations concerning the status of chiefs. The "Brief van een inlander uit de Minahassa", published in the Indische Gids 1891, 2, page 1235 and further, with a supporting post-scriptum by the editor, was proceedings against the editor; but the Governor-General saw insufficient reason for that (mailreport 923/1891 in Verbaal 10-3-1892/38 (ARA). The critical lecture given to the Indisch Genootschap by the widely respected former civil servant in Minahasa, F.S.A. de Clercq, in December 1891, proved most impressive in the public eye. (It is probable that he was the one who arranged the publication in Dutch dailies of letters sent by Minahasans.)

33. Source : Regeeringsalmanak, 1868-1891.

34. IG 1892, vol. 1, p. 846 and vol. 2, p. 1903.

35. Bataviaasch Handelsblad, 2-7-1892, also in mailreport 643/1892 (ARA).

36. The Controleur C.E.P. van Kerckhoff was assigned as a secretary to Gallois especially for the Minahasa-survey.

37. Letter by Stakman, dated Manado, 1-4-1892, no. 23, and response by Waworuntu, dated Sonder, 10-4-1892, no. 22, both in mailreport 720/1892, included in Verbaal 13-4-1983/56 (ARA). As soon as the Resident had noted Waworuntu's presence in Manado, he had already written a note to Gallois inquiring if the latter had summoned the chief of Sonder to the capital of the Residentie. Letter 22-3-1892, in collection Gallois, inventary 1 , lit. $\mathrm{H}$ (ARA).

38. Letter d.d. 29-3-1892, in collection Gallois, inv. 1, no. L1.

39. Letter d.d. 1-4-1892, no. 23 in Verbaal 14-4-1893/56.

40. Letter d.d. 10-4-1892, no. 22 in Verbaal 14-4-1893/56.

41. They would in later years use it in similar ways, to the extent that Dutchmen sometimes referred to the "kebratan (objection-) illness" of Minahasans. The socialist member of parliament $\mathrm{H}$. van Kol complained that during his visit to Minahasa in 1902, at any occasion dozens of petitions were handed to him (Van Kol, 279-280).

42. Letter d.d. 22-7-1892, no. 25 in Verbaal 13-4-1893/56, p. 36 and following.

43. See the article in Bataviaasch Handelsblad of 2-7-1892, "Stukken betreffende het jongste regeeringsonderzoek in de Minahassa", which contains inter alia minute accounts of the proceedings of Van Kerckhoff's session in Tumpa'an, the station of the junior chief of 
Sonder. This article is explicitly presented as consisting of accounts originating from Indonesian chiefs. Another important article is by Dwarskijker, "Een niet-officieel rapport van de zending-Gallois", in the Soerabaija-Courant of 25-6-1892, and several articles in the Bataviaasch Handelsblad, e.g. of 24-6-1892 and 8-7-1892. (Some of these are found in inv. no. 19 of the Collection-Gallois, ARA; these contain also reports on the surveys in other districts, e.g. Tondano Toulian.

44. Letter d.d. 22-7-1892, no. 25, p. 38 in Verbaal 13-4-1893/56.

45. Letter by Waworuntu, d.d. 21-3-1892, and the response by Gallois, d.d. 22-3-1892, both in Collection Gallois, inv. 1, lit. L.

46. See inv. nr. 8 of the Collection Gallois, and the letter of 41 pages to the Governor General, d.d. 22-7-1892, no. 25 in Verbaal 13-4-1893/56.

47. Gallois 1892.

48. See INI 1892, 2, 405-417. The M.P. Kielstra brought in an amendment for the abolition of the forced cultivation. He revoked this when another M.P. presented a motion to let the government monopoly expire. This motion was accepted against the will of the Minister of Colonial Affairs (see IG 1893, 1, p. 68-85). In November 1893 the motion put forward by Van Houten concerning the abolition of forced cultivation was accepted. In 1896 the government monopoly was actually abolished in Minahasa.

49. Gallois, 1892 , p. 52.

50. Advice by the Council of the Indies, in exhibitum 12-1-1893/87 (ARA). The Governor General argues there : "...the vigour of our government organism lies for a great part in the authority and influence of the native government».

51. Letter d.d. 22-7-1892, nr. 26, in Verbaal 13-4-1893/56, p. 8-9.

52. D.d. 2-9-1892, in mailreport 963/1892.

53. Stakman 1893.

54. E.g. Stakman 1893, page 52.

55. Resident van der Crab, in his Memorie van Overgave of 1875 , paid extensive attention to Minahasans who regularly read newspapers in the Dutch language (mailreport 645/1875, p. 25-26, 36-38). When the Indische Gids published in about 1880 some articles criticizing government policy in Minahasa, an immediate protest arose. This did not concern the contents of the articles in particular, but the probability that some educated Minahasans would read these. And that would undermine Dutch authority (Wijnmalen 634). In the period of the Gallois-survey, it was the critical lecture by De Clercq, published in the Handelingen van het Indisch Genootschap, that provoked such remarks (Swaving, p. 13).

56. Published respectively in Van Kesteren and in "Een Request».

57. In "Een andere lezing", p. 931.

58. Resident Matthes later referred to this action as a "temporary aberration" (Memorie van Overgave, mailreport 671/1882, p. 23-24).

59. It should be mentioned that A.J.F. Jansen, who was Resident of Manado from 1853 to 1859 , was then already convinced that, because of Christianization and progressing literacy, the mentality of the Minahasans, which he had up to then characterized as modest and docile, would change. They would gradually become more conscious of their situation and would not put up with it in the near future, a development which he did not consider as negative (Jansen, nota koffiekultuur 2-9-1857, in collection De Vriese no. 182, ARA).

60. At the time there were not yet opportunities for Indonesians to embark on a real intellectual career. From the first decades of the twentieth century on, some Minahasans were able to receive higher education. Among them was G.S.S.J. Ratulangi, who obtained a Ph.D. in science in Zürich in 1919, and became a prominent political leader back in Indonesia. 
61. It is here interesting to mention that in 1898 Waworuntu would again approach Pijnacker Hordijk, then a member of the Eerste Kamer (Senate). He appealed for support in the question of the Mines Bill (Mijnwet), which would be disavantageous to Minahasans (Letter dated Manado, November 26, 1898, collection Pijnacker Hordijk nr. 204, ARA). Pijnacker Hordijk asked for advice from Gallois, who turned out to have maintained vivid memories of Waworuntu. He remarked inter alia, that Waworuntu in 1891 «exploited an affection of the larynx... For a native chief, he is highly educated, writes excellently in the Dutch language, but is very self-conceited and has a far too high opinion of Minahasa, the Minahasan population, and most of all the Minahasan chiefs. Not too much dependence can be placed on his attachment and loyalty to the Dutch." (Letter without place and date, collection Pijnacker Hordijk nr. 193).

\section{REFERENCES}

Abdullah, Taufik : The making of a schakel society : the Minangkabau region in the late nineteenth century. Papers of the Dutch-Indonesian historical conference held at Noordwijkerhout, the Netherlands, 1976. Leiden/Jakarta 1978.

Een andere lezing over de Minahassa. IG 2 (1880) 1 : p. 929-931.

Clercq, F.S.A. de : De hervorming van het Minahasa-stelsel. Indische Genootschap, Vergadering van 8 December 1891. p. 203-231.

'Crab, P. van der : De Moluksche eilanden. Batavia 1862.

Gallois, W.O. : Rapport nopens den staat van zaken in de Minahassa. Batavia 1892.

Gent, L.F. van : Nederland-Menado (1896-1921). Weltevreden 1923.

Gouvernements-koffiekultuur in de residentie Menado. TNI 23 (1894) 2 : p. 161-218.

Graafland, N. : De Minahassa. 1st edition, Rotterdam 1867.

Hoekzema, Z.B. : Een en ander over de toestanden in de Minahassa. Mededeelingen vanwege het Nederlandsche Zendelingsgenootschap 37 (1893) : p. 261-272.

De Indische begrooting voor 1893 in de Tweede Kamer. TNI 21 (1892) 2 : p. 412-418.

Jansen, A.J.F. : De landbouw in de Minahasa van Menado in 1853. Tijdschrift Bataviaasch Genootschap 10 (1861) : p. 221-258.

Jellesma, E.J. and Waworuntu, A.L. : Bijdragen tot de kennis van het Tompakewasch. Verhandelingen van het Bataviaasch Genootschap van Kunsten en Wetenschappen, 1892. Volume 47, part 1, p. 1-100.

Kesteren, C.E. van : De "vriendschap" der Indische regeering aan de bevolking der afdeeling Minahassa. $I G 1$ (1879) 1 : p. 449-468.

Kol, H. van : Uit onze koloniën. Leiden 1903.

Kolonial Verslag van 1879. Bijlagen van het verslag der handelingen van de tweede kamer der Staten-Generaal 1879-1880. 's-Gravenhage 1880.

Een motie tot afschaffing van de gouvernements-koffiekultuur in de Minahassa. IG 15 (1893) $1:$ p. $68-85$.

Quarles van Ufford, H. : Aanteekeningen betreffende eene reis door de Molukken. 's-Gravenhage 1856.

Regeeringsalmanak voor Nederlandsch-Indï, 1869-1892. Batavia, Landsdrukkerij, 1868-1891. 
Reinwardt, C.G.C. : Reis naar het Oostelijk gedeelte van den Indischen archipel in het jaar 1821. Amsterdam 1858.

Een request uit de Minahassa aan de Tweede Kamer. IG 1 (1879) 2 : p. 112-114.

[Stakman, M.C.E. :] Het rapport van den resident van Menado over het verslag van den koffiecommissie; met eenige kantteekeningen. $I G 14$ (1892) 1 : p. 820-844.

Stakman, M.C.E. : De Minahassa. Bezwaarschrift. Amsterdam 1893.

Sutherland, H.A. : The priyayi. Indonesia 19 (April 1975) : p. 57-77.

Sutherland, H.A. : The making of a bureaucratic elite. Singapore 1979.

Swaving, A.H. : Nabetrachting. Het Minahassa-rapport. (reprint from De Java-Bode) 1892.

Wessels, L. : De gouvernements-koffiecultuur in de Minahassa, residentie Menado. TNI 22 (1891) 1 : p. 50-71; p. 123-146.

Wijnmalen, P.C. : Een protest tegen het artikel van den heer Bosscher over het tegenwoordige regeeringsbeleid in de residentie Menado. IG 2 (1880) 1 : p. 634-640.

Many brief articles in the sections "Varia" and "Maandelijksche Revue van Brochures en van Tijdschrift- en Dagbladartikelen" in the Indische Gids, 1892.

Abbreviations:

IG : Indische Gids.

TNI : Tijdschrift voor Nederlandsch-Indië.

NEWSPAPERS :

Algemeen Handelsblad, August 9, 1891.

Bataviaasch Handelsblad, June 24 and July 2 and 8, 1892.

Indische Tolk van het Nieuws van den Dag, June 26, 1894.

De Locomotief, June 11 and 25, 1892.

Nieuwe Rotterdamsche Courant, January 11, 1893.

Soerabaija Courant, May 21 and June 25, 1892.

Het Vaderland, August 25 and September 16 and 17, 1892.

Archival Sources :

Algemeen Rijksarchief, The Hague (ARA).

Arsip Nasional, Jakarta (Arnas). 